\title{
Downregulation of trefoil factor-3 expression in the rectum is associated with the development of ulcerative colitis-associated cancer
}

\author{
SATORU KONDO, TOSHIMITSU ARAKI, YUJI TOIYAMA, KOJI TANAKA, \\ MIKIO KAWAMURA, YOSHINAGA OKUGAWA, YOSHIKI OKITA, SUSUMU SAIGUSA, \\ YASUHIRO INOUE, KEIICHI UCHIDA, YASUHIKO MOHRI and MASATO KUSUNOKI \\ Department of Gastrointestinal and Pediatric Surgery, Division of Reparative Medicine, \\ Institute of Life Sciences, Mie University Graduate School of Medicine, Tsu, Mie 514-8507, Japan
}

Received May 19, 2016; Accepted February 28, 2017

DOI: $10.3892 / \mathrm{ol} .2018 .9120$

\begin{abstract}
Diagnostic markers facilitate more selective screening and treatment strategies for ulcerative colitis (UC)-associated cancer (UCAC). The expression of trefoil factor-3 (TFF3), which is involved in mucosal protection and repair in the gastrointestinal tract, was analyzed and its significance for UCAC was evaluated. A total of 145 patients with UC who underwent proctocolectomies were enrolled, including 15 patients (10.8\%) with UCAC. TFF3 expression in the rectal mucosa and in cancer cells was assessed using immunohistochemistry, and the expression in UCAC and sporadic colorectal cancer was compared. Analyzing the mucinous granules of goblet cells located in crypts revealed that the non-cancerous rectal mucosa of patients with UCAC had significantly lower mean TFF3 staining scores compared with patients with UC without UCAC or patients with sporadic cancer. TFF3 staining score was revealed to be an independent predictor of UCAC development. These results indicated that low TFF3 expression in the rectal mucosa was associated with the development of UCAC. Thus, TFF3 expression in the rectal mucosa may be a useful biomarker for monitoring patients with UC.
\end{abstract}

\section{Introduction}

Ulcerative colitis (UC) is the most common form of inflammatory bowel disease, and is characterized by chronic inflammation of the gastrointestinal tract (1). UC-associated

Correspondence to: Dr Toshimitsu Araki, Department of Gastrointestinal and Pediatric Surgery, Division of Reparative Medicine, Institute of Life Sciences, Mie University Graduate School of Medicine, 2-174 Edobashi, Tsu, Mie 514-8507, Japan E-mail: taraki@clin.medic.mie-u.ac.jp

Key words: trefoil factor-3, ulcerative colitis, colitis-associated cancer, field effect, surveillance cancer (UCAC) is thought to arise from widespread alterations caused by a combination of genetic and epigenetic factors, as well as host and microbial influences, and is also known as an inflammation dysplasia carcinoma sequence, which differs from sporadic colon cancer $(2,3)$. Patients with UC have an increased risk of developing colorectal cancer; and UC that is persistent or covers a large area is a risk factor for UCAC (4). The cumulative risk probability of UCAC was reported to be $2 \%$ following 10 years, $8 \%$ following 20 years and $18 \%$ following 30 years of disease duration (5). Furthermore, Munkholm (6) demonstrated that $15 \%$ of all mortality among UC patients was caused by UCAC. In contrast, a more recent meta-analysis by Jess et al (7) revealed that only $1.6 \%$ of patients with UC developed UCAC within 14 years of diagnosis. While certain studies concerning endoscopic surveillance programs for precancerous dysplasia in patients with inflammatory bowel disease have reported that surveillance reduces the mortality rate from colorectal carcinoma $(8,9)$, other studies have highlighted a failure to do so $(7,10,11)$. The influence of these surveillance systems on the mortality rates of patients with UC requires clarification. Furthermore, patients with long-term UC require effective diagnostic markers. Although several biomarkers appear to correlate with colorectal cancer, including p53, KRAS proto-oncogene, GTPase and APC, WNT signaling pathway regulator, these are not effective for detecting UCAC.

Trefoil factors are a family of peptides with a distinct three-loop structure formed by a highly conserved motif of cysteine disulfide bonds that confer notable luminal stability $(12,13)$. The three genes that produce the trefoil family proteins are located within a $55 \mathrm{~kb}$ region on human chromosome 21q22.3 (14). Trefoil factor 1 (TFF1, also known as pS2) and trefoil factor 2 (also known as spasmolytic polypeptide) are normally expressed by epithelial cells of the stomach and duodenum. Trefoil factor 3 (TFF3, also known as intestinal trefoil factor) is predominantly expressed by goblet cells of the small intestine and colon (15). Trefoil peptides have been implicated in the processes of gastrointestinal restitution and repair (14,16-18), and their ability to promote epithelial cell migration $(19,20)$ while preventing apoptosis and anoikis (18) facilitates these normal physiologic processes. 
Trefoil factors have also been reported to participate in neoplasia. For example, in the stomach, TFF3 expression is normally weak or absent $(15,21)$, but is expressed in areas of intestinal metaplasia (22-24) and in $~ 50 \%$ of gastric carcinomas $(23,24)$. Furthermore, when expressed by gastric carcinomas, TFF3 is associated with poor prognosis, independent of tumor stage $(23,24)$. TFF3 expression in cancer cells has also been reported to be associated with tumor progression in colon cancer $(25,26)$.

However, to the best of our knowledge, no previous study has explored the association between TFF3 expression and UCAC. The present study therefore investigated whether TFF3 expression in the rectal mucosa predicted UCAC development.

\section{Materials and methods}

Patients and samples. A total of 118 formalin-fixed, paraffin-embedded (FFPE) tissue samples of tumors from patients with sporadic colorectal cancer who underwent colectomies from January 2010 to December 2011 at the Mie University Hospital (Tsu, Japan), and 15 FFPE tissue samples of tumors from patients with UCAC were used in the present study. Patient characteristics are listed in Table I. No patients underwent any pre-surgical treatment. Patients with incomplete clinical data, inadequate follow-up information and/or inadequate immunohistochemical analysis were excluded. A total of 50 FFPE tissue samples of adjacent normal rectum from patients with sporadic rectal cancer and 145 FFPE tissue samples of adjacent normal rectum from patients with UC who underwent proctocolectomies from January 2003 to December 2011 at the Mie University Hospital were also examined, including 15 UCAC patients. Patient characteristics are listed in Table II. Patients with incomplete clinical data, inadequate follow-up information and/or inadequate immunohistochemical analysis were excluded.

All patients provided written, informed consent according to the local ethics guidelines, and the study design was approved by the Ethics Review Board of Mie University Hospital.

Immunohistochemistry. The tumor and rectum FFPE tissue were sliced into $3 \mu \mathrm{m}$ sections. Following deparaffinization by xylene and rehydration by ethanol gradients $(100,90$ and $75 \%$ ), the sections were pretreated in an autoclave at $121^{\circ} \mathrm{C}$ for $10 \mathrm{~min}$ in $10 \mathrm{mM}$ citrate buffer ( $\mathrm{pH} \mathrm{6.0)}$ ) for antigen retrieval. Endogenous peroxidase activity was blocked by incubation for $10 \mathrm{~min}$ in $3 \%$ hydrogen peroxide. Nonspecific-binding sites were blocked in $1 \mathrm{~mol} / \mathrm{l} \mathrm{PBS}$ with $10 \%$ normal goat serum (Vector Laboratories, Inc., Burlingame, CA, USA) for $1 \mathrm{~h}$ at $20^{\circ} \mathrm{C}$. The sections were then incubated with a primary rabbit monoclonal antibody against TFF3 (EPR3974; cat. no. ab108599; 1:1,000; Abcam, Cambridge, UK) in PBS containing $1 \%$ bovine serum albumin (Sigma-Aldrich; Merck $\mathrm{KGaA}$, Darmstadt, Germany) for $1 \mathrm{~h}$ at $20^{\circ} \mathrm{C}$. Following washing with PBS, sections were loaded with a secondary antibody coupled with peroxidase-conjugated polymers (Envision+Dual Link System-horseradish peroxidase (rabbit anti-mouse; cat. no. K4065; Dako; Agilent Technologies, Inc., Santa Clara, CA, USA) for $30 \mathrm{~min}$ at $20^{\circ} \mathrm{C}$. The primary antibodies were subsequently detected using 3,3'-diaminobenzidine (Dako). All sections were counterstained with Mayer's hematoxylin, dehydrated in ethanol gradients (90 and 100\%) and mounted. Negative control sections were prepared by omitting the primary antibody. The FFPE rectum specimens were also sliced into continual $5 \mu \mathrm{m}$ sections and stained using the histochemical technique for Mayer's mucicarmine (Mayer's Mucicarmine Stain Solution; Sigma-Aldrich; Merck $\mathrm{KGaA}$ ), as previously described (27), to confirm the presence of mucin.

Evaluation of immunoreactive TFF3 protein. Each slide was observed by scanning the whole section at medium (x40) and high (x200) magnification under a light microscope. The immunoreactivity scoring system was based on the intensity and extent of staining. The criteria were as follows: i) The intensity of TFF3 staining was scored as 0 (negative), 1 (weak), 2 (medium), or 3 (strong); ii) the percentage of positive-staining cancer cells on tumor specimens or positive-staining epithelial cells in the crypts of the rectum specimens as $0(0-5 \%)$, $1(6-25 \%), 2$ (26-50\%), $3(51-75 \%)$, or 4 (76-100\%). The results of i) and ii) were multiplied together to obtain the TFF3 staining scores (range: 0-12), which thus reflected the intensity and extent of the stained cells. Each sample was scored in a blind manner by two independent researchers with no prior information concerning clinical or pathological parameters of the patients. The few discrepancies were resolved using a multi-head light microscope, and consensus was then reached for each slide.

Statistical analysis. All statistical analyses were performed using JMP version 12 software (SAS Institute, Inc., Cary, NC, USA). Results are expressed as the mean \pm standard deviation. Contingency tables were analyzed using the $\chi^{2}$ test with Yates' correction. Differences between two groups were evaluated using the Mann-Whitney U test. Logistic regression was used to analyze whether TFF3 expression in rectal mucosa predicted UCAC development. $\mathrm{P}<0.05$ was considered to indicate a statistically significant difference.

\section{Results}

Patient demographics and disease characteristics. The characteristics of the patients with UC are listed in Table I. The median age at UC diagnosis was 28 years (range: $0-82$ years), and the median disease duration was 6 years. A total of 69,61 , and 15 patients had mild, moderate, and severe inflammation, respectively.

The UCAC and non-cancer groups did not significantly differ in sex, age at UC diagnosis, or degree of inflammation (Table I). The median age of the UCAC group (48 years) was higher than that of the non-cancer group (33 years; $\mathrm{P}<0.01$ ). The UCAC group also had a significantly longer median disease duration (12 years) than the non-cancer group (6 years; $\mathrm{P}<0.01$ ).

Characteristics of patients with sporadic colorectal cancer are listed in Table II. A total of 118 patients (63 men and 55 women) were enrolled in this group. The mean age was 67 years (range: 35-89 years). Patients were classified according to the tumor-node-metastasis (TNM) classification by the Union for International Cancer Control (28), and 25 patients had stage I disease, 33 had stage II, 34 had stage III and 26 had stage IV.

Immunohistochemical results and evaluation of TFF3 expression. For UCAC and sporadic cancer, TFF3 expression 
Table I. Characteristics of patients with and without UC-associated cancer.

\begin{tabular}{lcccr}
\hline Characteristic & All patients (n=145) & UCAC (n=15) & Non-cancer (n=130) & P-value \\
\hline Sex, n (male/female) & $81 / 64$ & $10 / 5$ & $71 / 59$ & 0.37 \\
Age, years (range) & $(15-82)$ & $(28-74)$ & $(15-82)$ & $<0.01^{\text {a }}$ \\
Age at diagnosis, years (range) & $(0-82)$ & $(17-63)$ & $(0-82)$ & 0.12 \\
Disease duration, years (range) & $6(0-37)$ & $(0-26)$ & $6(0-37)$ & $<0.01^{\text {a }}$ \\
Degree of inflammation & & & & 0.28 \\
Mild, $n$ (\%) & $(48)$ & $9(60)$ & $(45)$ & \\
Moderate or severe, $\mathrm{n}(\%)$ & $(52)$ & $6(40)$ & $(55)$ & \\
\hline
\end{tabular}

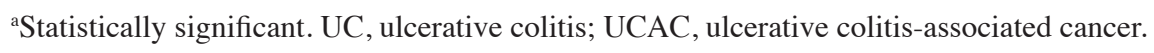

Table II. Characteristics of patients with sporadic cancer.

\begin{tabular}{lc}
\hline Characteristic & Value \\
\hline Sex, n (male/female) & $63 / 55$ \\
Age, years (range) & $(35-89)$ \\
T category, n (1/2/3/4) & $23 / 12 / 58 / 25$ \\
Lymph node metastasis, n (negative/positive) & $64 / 54$ \\
Liver metastasis, n (negative/positive) & $107 / 11$ \\
Peritoneal carcinomatosis, n (negative/positive) & $107 / 11$ \\
Distant metastasis, n (negative/positive) & $99 / 19$ \\
TNM stage, n (I/II/III/IV) & $25 / 33 / 34 / 26$
\end{tabular}

TNM, tumor-node-metastasis.

was localized in the cytoplasm, with no expression in the nucleus or cell membrane (Fig. 1A and B, respectively). The mean TFF3 staining scores were significantly lower in the cytoplasm of UCAC cancer cells $(2.00 \pm 2.24)$ compared with sporadic cancer cells ( $3.81 \pm 2.84 ; \mathrm{P}<0.01 ;$ Fig. 2$)$.

In non-cancerous rectal mucosa, TFF3 expression was primarily observed in the mucinous granules of goblet cells from the intestinal crypts (Fig. 3A-C); and was confirmed by Mayer's mucicarmine-stained mucin in adjacent sections (Fig. 3D). In the mucinous granules of the goblet cells in the crypts, the mean TFF3 staining score for non-cancerous rectal mucosa from patients with UCAC (4.53 \pm 2.36$)$ was significantly lower $(\mathrm{P}<0.01)$ than that from UC patients without UCAC (7.21 \pm 3.38 ) or with sporadic cancer (7.58 \pm 2.72 ; Fig. 4). Weak TFF3 expression was observed in the goblet cell cytoplasm, but not in the nuclei or cell membranes.

Associations of TFF3 expression in the rectal mucosa with clinical outcomes. TFF3 staining scores were significantly lower in patients who were older $(\mathrm{P}<0.01$; Table III), had early-onset disease $(\mathrm{P}<0.01$; Table III), had a longer disease duration $(\mathrm{P}<0.01$; Table III), had mild disease severity $(\mathrm{P}=0.04$; Table III), or who were in the UCAC group $(\mathrm{P}<0.01$; Table III).

The median values of TFF3 staining score and the other factors were used as the cut-off values. Univariate analysis revealed that age [ $\geq 34$ years; odds ratio (OR), 4.13;
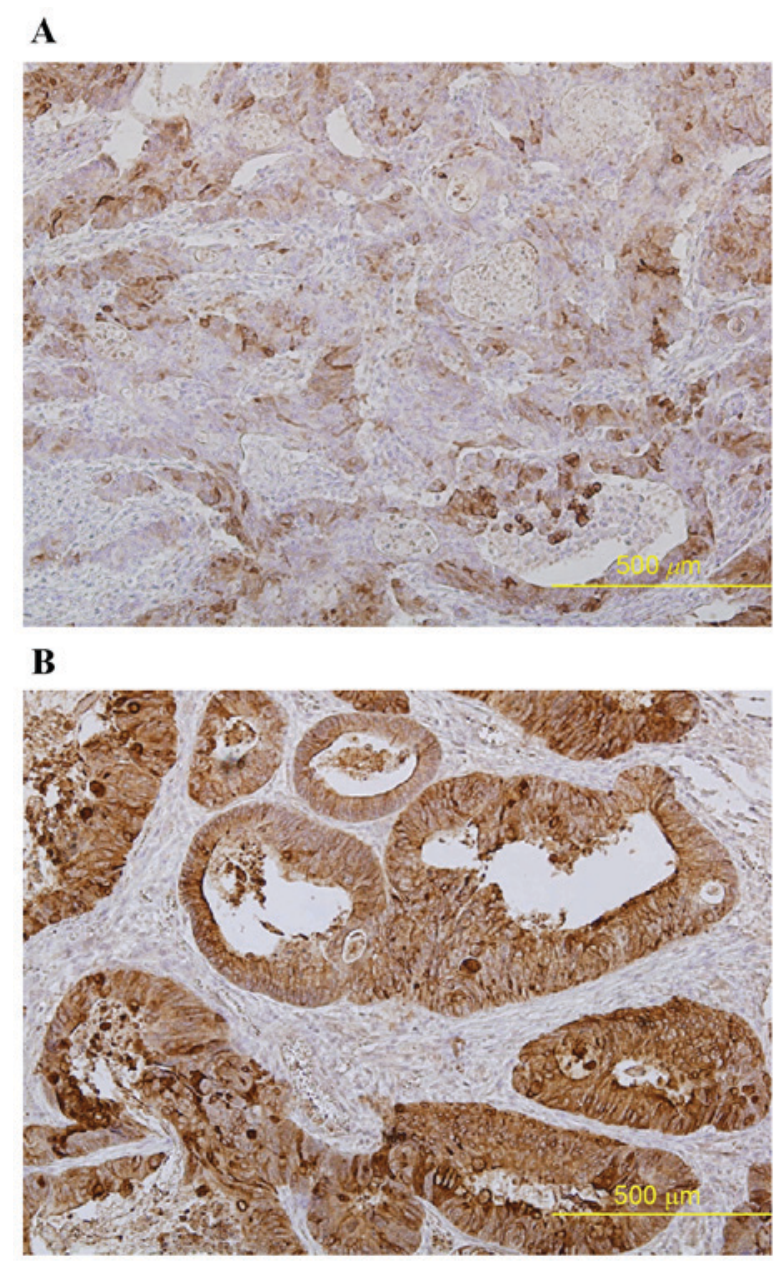

Figure 1. Immunohistochemical analysis of TFF3 expression in tumor cells. TFF3 expression was observed in the cytoplasm of (A) ulcerative colitis-associated cancer and (B) sporadic colorectal cancer cells (magnification, x100). TFF3, trefoil factor-3.

95\% confidence interval $(\mathrm{CI}), 1.24-18.7 ; \mathrm{P}=0.02$; Table IV], disease duration (OR, 3.88; 95\% CI, 1.17-17.6; $\mathrm{P}=0.03$; Table IV), and TFF3 staining score (OR, 6.70; 95\% CI, 1.76-44.0; $\mathrm{P}<0.01$; Table IV) were significantly associated with UCAC development. Multivariate analysis revealed that TFF3 staining score was an independent predictor of UCAC development (OR, 4.32; 95\% CI; 1.01-29.9; $\mathrm{P}=0.05$ ). 


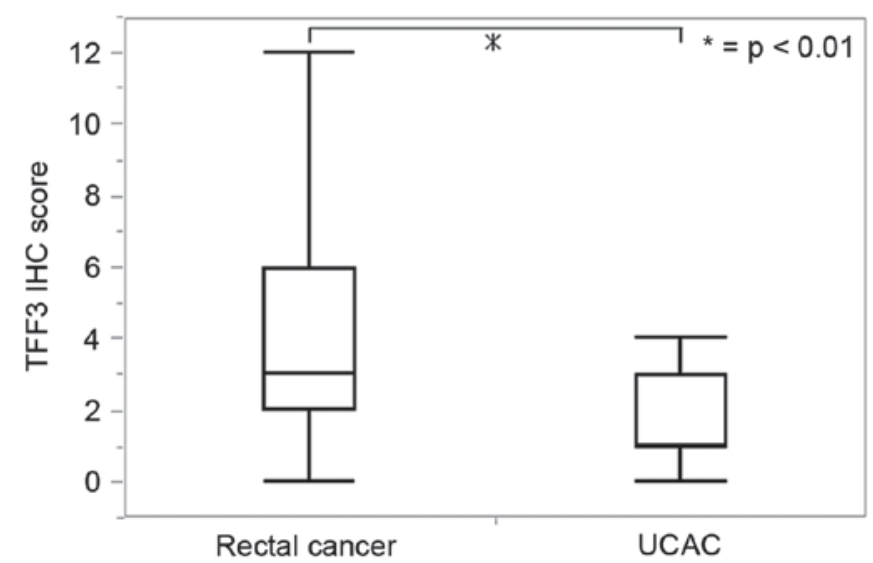

Figure 2. TFF3 expression in cancer tissues, as analyzed by IHC. ${ }^{*} \mathrm{P}<0.01$ vs. rectal cancer. TFF3, trefoil factor-3; IHC, immunohistochemistry; UCAC, ulcerative colitis-associated cancer.
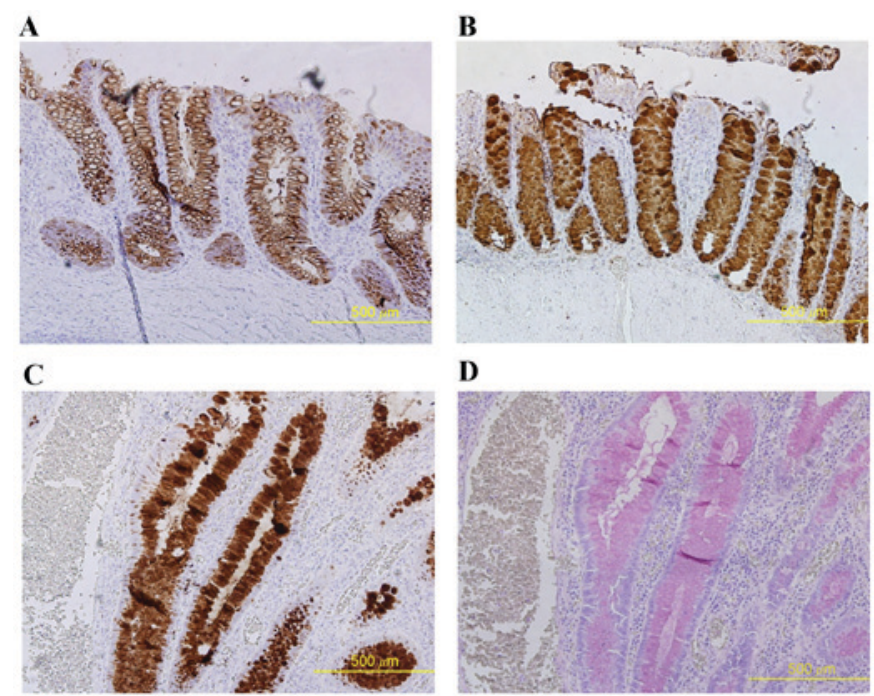

D

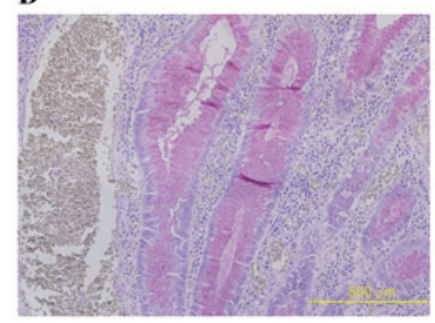

Figure 3. Representative slides of rectal mucosa from patients with ulcerative colitis, comparing expression patterns for mucinous granules and TFF3 in goblet cells. TFF3 is stained in brown. All patients demonstrated extensive TFF3 staining in the rectal mucosa, of either (A) weak intensity, (B) medium intensity and (C) strong intensity. (D) Mucinous granules in goblet cells, stained by Mayer's mucicarmine stain, from a serial section of (C). Magnification, x100. TFF3, trefoil factor-3.

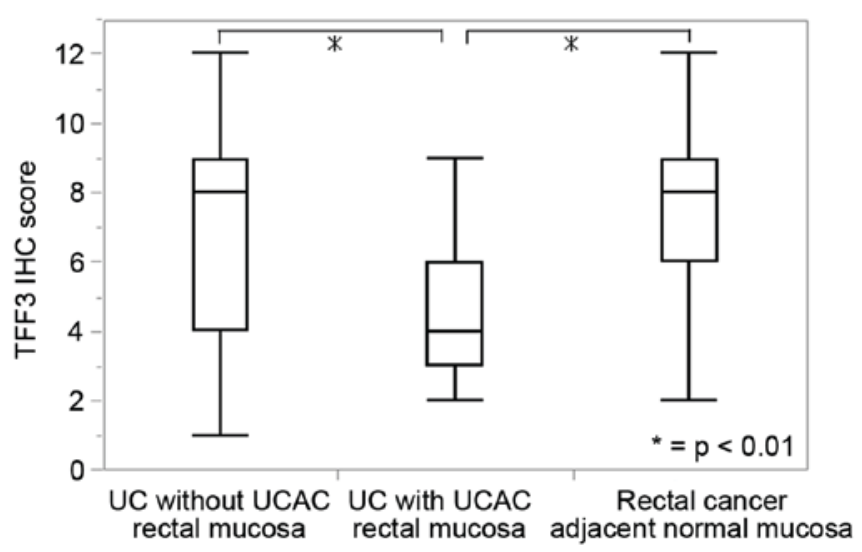

Figure 4. TFF3 expression in goblet cells in the crypts, as analyzed by IHC. ${ }^{*} \mathrm{P}<0.01$, with comparisons indicated by lines. TFF3, trefoil factor-3; IHC, immunohistochemistry; UCAC, ulcerative colitis-associated cancer.
Table III. Association of TFF3 expression in the rectal mucosa with clinical outcomes.

\begin{tabular}{|c|c|c|c|}
\hline Characteristic & $\mathrm{n}$ & $\begin{array}{c}\text { TFF3 } \\
\text { staining score }\end{array}$ & P-value \\
\hline Sex & & & 0.88 \\
\hline Male & 81 & $6.93 \pm 3.24$ & \\
\hline Female & 64 & $6.88 \pm 3.64$ & \\
\hline Age, years & & & $<0.01^{\mathrm{a}}$ \\
\hline$<34$ & 69 & $8.06 \pm 2.88$ & \\
\hline$\geq 34$ & 76 & $5.86 \pm 3.53$ & \\
\hline Age at UC diagnosis, years & & & $<0.01^{\mathrm{a}}$ \\
\hline$<27$ & 70 & $7.69 \pm 2.92$ & \\
\hline$\geq 27$ & 75 & $6.17 \pm 3.68$ & \\
\hline Duration of disease, years & & & $<0.01^{\mathrm{a}}$ \\
\hline$<6$ & 67 & $8.07 \pm 3.13$ & \\
\hline$\geq 6$ & 78 & $5.90 \pm 3.34$ & \\
\hline \multicolumn{4}{|l|}{ Degree of inflammation } \\
\hline Mild & 68 & $6.29 \pm 3.33$ & $0.04^{\mathrm{a}}$ \\
\hline Moderate or severe & 77 & $7.44 \pm 3.40$ & \\
\hline UCAC status & & & $<0.01^{\mathrm{a}}$ \\
\hline UCAC & 15 & $4.53 \pm 2.36$ & \\
\hline Non-cancer & 130 & $7.18 \pm 3.41$ & \\
\hline
\end{tabular}

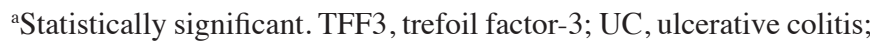
UCAC, ulcerative colitis-associated cancer.

\section{Discussion}

In the present study, TFF3 expression was lower in the rectal mucosa and cancer cells of patients with UCAC than in the other tested groups. Notably, this relationship differed from that observed in other types of cancer, in which upregulated TFF3 expression is correlated with progressive staging and more aggressive malignancies (25,29-33). For example, high expression of TFF3 in serum and cancer cells was associated with poor prognosis in gastric cancer (31), breast cancer (32), and advanced prostate cancer (33). In addition, in colon cancer, high TFF3 expression in cancer cells is reportedly associated with metastasis and early recurrence $(25,26)$, and high serum TFF3 expression levels are associated with distant metastasis and TNM stages III and IV (29). In contrast, weak TFF3 expression in cancer cells has been reported to be associated with colon carcinogenesis (30). The significance of TFF3 expression in colorectal cancer is, therefore, controversial.

TFF3 itself is primarily produced by the colorectal mucosa, which is made up of a single layer of simple tubular glands and crypts (15). Pluripotent stem cells in the crypt bottoms differentiate into goblet cells, entero-endocrine cells and absorptive cells. Goblet cells contain abundant mucinous granules, which it is possible to stain using Mayer's mucicarmine, and secrete a complex mixture of mucin glycoproteins at the luminal surface (34). Colon goblet cells also secrete TFF3 (35). Thus, TFF3 in the colorectal mucosa is predominantly expressed in the mucinous granules of goblet cells. On the other hand, 
Table IV. Univariate and multivariate analysis of factors that influence UCAC.

\begin{tabular}{|c|c|c|c|c|c|c|}
\hline \multirow[b]{2}{*}{ Factors } & \multicolumn{3}{|c|}{ Univariate } & \multicolumn{3}{|c|}{ Multivariate } \\
\hline & OR & $95 \% \mathrm{CI}$ & P-value & OR & $95 \%$ CI & P-value \\
\hline Sex & & & & & & \\
\hline Male vs. female & 1.66 & $0.55-5.58$ & 0.37 & & & \\
\hline $\begin{array}{l}\text { Age, years } \\
\geq 34 \text { vs. }<34\end{array}$ & 4.13 & $1.24-18.7$ & $0.02^{\mathrm{a}}$ & 1.83 & $0.13-18.7$ & 0.62 \\
\hline $\begin{array}{l}\text { Age at UC diagnosis, years } \\
<27 \text { vs. } \geq 27\end{array}$ & 2.84 & $0.92-10.7$ & $0.07^{\mathrm{a}}$ & 1.25 & 0.18-14.6 & 0.84 \\
\hline $\begin{array}{l}\text { Duration of disease, years } \\
\geq 6 \text { vs. }<6\end{array}$ & 3.88 & $1.17-17.6$ & $0.03^{\mathrm{a}}$ & 2.45 & $0.66-11.8$ & 0.19 \\
\hline $\begin{array}{l}\text { Degree of inflammation } \\
\text { Mild vs. moderate or severe }\end{array}$ & 1.81 & $0.62-5.66$ & 0.28 & & & \\
\hline $\begin{array}{l}\text { TFF3 staining score } \\
<7 \text { vs. } \geq 7\end{array}$ & 6.7 & $1.76-44.0$ & $<0.01^{\mathrm{a}}$ & 4.32 & $1.01-29.9$ & $0.05^{\mathrm{a}}$ \\
\hline
\end{tabular}

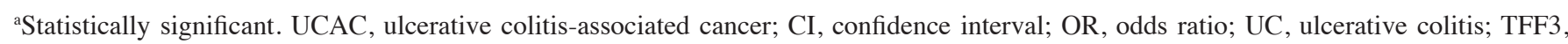
trefoil factor-3.

TFF3 synthesis by non-goblet colonocytes is highly conserved in neoplastic differentiation (36). These dissimilar characteristics of TFF3 in the colorectal mucosa and cancer cells, and differing sequences of inflammation-dysplasia-carcinoma and adenoma-carcinoma, may explain the discrepancy of downregulated TFF3 correlating with UCAC development.

TFF3 increases mucin gel viscosity, and also mediates epithelial restitution and migration in colonic mucosa $(17,20)$. TFF3 is upregulated at the margins of mucosal injury and in various ulcerative conditions, which implies an important function in mucosal defense and repair (37). TFF3-deficient mice demonstrated poor epithelial colonic regeneration following oral administration of dextran sulfate sodium (38). Inflammation in the UCAC colon may often be inactive, which may lead to low expression levels of TTF3, but it was the TFF3 staining score rather than the degree of inflammation that was recorded as an independent predictor of UCAC development in the present study.

For patients with long-term UC, current surveillance guidelines recommend colonoscopies with random biopsies to be collected at $10 \mathrm{~cm}$ increments along the colonic mucosa or target biopsy testing every 1-2 years (39-42). Although surveillance colonoscopies help to detect early-stage UCAC and reduce the risk of mortality (43-45), this type of surveillance has several limitations, including sampling errors and difficulties in macroscopic diagnosis of neoplastic lesions that are flat or diffusely infiltrative $(46,47)$. Based on the field effect concept, which states that neoplastic and non-neoplastic tissues may harbor widespread genetic alterations $(48,49)$, multiple investigators have attempted to determine effective biomarkers to identify patients with UC who are at a higher risk of developing UCAC (50-52). However, these biomarkers have not been well established.

In conclusion, the results of the present study revealed that TFF3 downregulation in the rectal mucosa was associated with UCAC development. Thus, a combination of current surveillance and evaluation of TFF3 expression in the rectal mucosa may successfully and safely identify high-risk patients with UCAC. However, these data should be interpreted with caution. A selection bias was present, as the patients in the present study were not representative of a typical patient population under surveillance. The present study also included relatively few patients with UCAC. Further studies are therefore planned for the future, potentially including prospective multicenter studies of biopsy samples from patients with UC, to assess the utility of TFF3 expression as a marker for routine clinical use.

\section{Acknowledgements}

The authors would like to thank Ms. Marla Brunker for editing a draft of this manuscript.

\section{Funding}

No funding was received.

\section{Availability of data and materials}

The datasets used and analyzed during the current study are available from the corresponding author on reasonable request.

\section{Authors' contributions}

SK analyzed and interpreted the data and wrote the initial draft of the manuscript. TA made substantial contributions to acquisition of data, was involved in drafting the manuscript and revising it critically for important intellectual content, gave final approval of the version to be published and agreed to be accountable for all aspects of the work in ensuring that questions related to the accuracy or integrity of any part of the 
work. KT contributed to design the study. YT, MKa, YOku, YOki, SS, YI, KU, YM and MKu contributed to data collection and interpretation, and critically reviewed the manuscript. All authors approved the final version of the manuscript and agreed to be accountable for all aspects of the work in ensuring that questions related to the accuracy or integrity of any part of the work are appropriately investigated and resolved.

\section{Consent for publication}

Written informed consent was obtained from the patient for publication of this manuscript.

\section{Competing interests}

The authors declare that they have no competing interests.

\section{References}

1. de Dombal FT, Burch PR and Watkinson G: Aetiology of ulcerative colitis. Gut 10: 270-277, 1969.

2. Cho JH and Brant SR: Recent insights into the genetics of inflammatory bowel disease. Gastroenterology 140: 1704-1712, 2011.

3. Thompson AI and Lees CW: Genetics of ulcerative colitis. Inflamm Bowel Dis 17: 831-848, 2011.

4. Danese S and Fiocchi C: Ulcerative colitis. N Engl J Med 365: 1713-1725, 2011

5. Eaden JA, Abrams KR and Mayberry JF: The risk of colorectal cancer in ulcerative colitis: A meta-analysis. Gut 48: 526-535, 2001.

6. Munkholm P: Review article: The incidence and prevalence of colorectal cancer in inflammatory bowel disease. Aliment Pharmacol Ther 18 (Suppl 2): S1-S5, 2003.

7. Jess T, Rungoe $C$ and Peyrin-Biroulet L: Risk of colorectal cancer in patients with ulcerative colitis: A meta-analysis of population-based cohort studies. Clin Gastroenterol Hepatol 10: 639-645, 2012.

8. Choi PM, Nugent FW, Schoetz DJ Jr, Silverman ML and Haggitt RC: Colonoscopic surveillance reduces mortality from colorectal cancer in ulcerative colitis. Gastroenterology 105: 418-424, 1993.

9. Vleggaar FP, Lutgens MW and Claessen MM: Review article: The relevance of surveillance endoscopy in long-lasting inflammatory bowel disease. Aliment Pharmacol Ther 26 (Suppl 2): S47-S52, 2007.

10. Jess T, Frisch $M$ and Simonsen J: Trends in overall and cause-specific mortality among patients with inflammatory bowel disease from 1982 to 2010. Clin Gastroenterol Hepatol 11: 43-48, 2013.

11. Herrinton LJ, Liu L, Levin TR, Allison JE, Lewis JD and Velayos F: Incidence and mortality of colorectal adenocarcinoma in persons with inflammatory bowel disease from 1998 to 2010 Gastroenterology 143: 382-389, 2012.

12. Poulsom R and Wright NA: Trefoil peptides: A newly recognized family of epithelial mucin-associated molecules. Am J Physiol 265: G205-G213, 1993.

13. Thim L: Trefoil peptides: A new family of gastrointestinal molecules. Digestion 55: 353-360, 1994.

14. Wright NA, Poulsom R, Stamp G, Van Noorden S, Sarraf C Elia G, Ahnen D, Jeffery R, Longcroft J, Pike C, et al: Trefoil peptide gene expression in gastrointestinal epithelial cells in inflammatory bowel disease. Gastroenterology 104: 12-20, 1993.

15. Madsen J, Nielsen O, Tornøe I, Thim L and Holmskov U: Tissue localization of human trefoil factors 1, 2, and 3. J Histochem Cytochem 55: 505-513, 2007.

16. Farrell JJ, Taupin D, Koh TJ, Chen D, Zhao CM, Podolsky DK and Wang TC: TFF2/SP-deficient mice show decreased gastric proliferation, increased acid secretion, and increased susceptibility to NSAID injury. J Clin Invest 109: 193-204, 2002.

17. Babyatsky MW, deBeaumont M, Thim L and Podolsky DK: Oral trefoil peptides protect against ethanol- and indomethacin-induced gastric injury in rats. Gastroenterology 110 489-497, 1996
18. Taupin D and Podolsky DK: Trefoil factors: Initiators of mucosal healing. Nat Rev Mol Cell Biol 4: 721-732, 2003.

19. Kinoshita K, Taupin DR, Itoh H and Podolsky DK: Distinct pathways of cell migration and antiapoptotic response to epithelial injury: Structure-function analysis of human intestinal trefoil factor. Mol Cell Biol 20: 4680-4690, 2000.

20. Dignass A, Lynch-Devaney K, Kindon H, Thim L and Podolsky DK: Trefoil peptides promote epithelial migration through a transforming growth factor beta-independent pathway. J Clin Invest 94: 376-383, 1994.

21. Kirikoshi $\mathrm{H}$ and Katoh M: Expression of TFF1, TFF2 and TFF3 in gastric cancer. Int J Oncol 21: 655-659, 2002.

22. Leung WK, Yu J, Chan FK, To KF, Chan MW, Ebert MP, Ng EK, Chung SC, Malfertheiner P and Sung JJ: Expression of trefoil peptides (TFF1, TFF2, and TFF3) in gastric carcinomas, intestinal metaplasia, and non-neoplastic gastric tissues. J Pathol 197: $582-588,2002$

23. Yamachika T, Werther JL, Bodian C, Babyatsky M, Tatematsu M, Yamamura Y, Chen A and Itzkowitz S: Intestinal trefoil factor: A marker of poor prognosis in gastric carcinoma. Clin Cancer Res 8: 1092-1099, 2002.

24. Dhar DK, Wang TC, Tabara H, Tonomoto Y, Maruyama R, Tachibana M, Kubota $\mathrm{H}$ and Nagasue N: Expression of trefoil factor family members correlates with patient prognosis and neoangiogenesis. Clin Cancer Res 11: 6472-6478, 2005.

25. Morito K, Nakamura J, Kitajima Y, Kai K, Tanaka T, Kubo H, Miyake $\mathrm{S}$ and Noshiro H: The value of trefoil factor 3 expression in predicting the lon-gterm outcome and early recurrence of colorectal cancer. Int J Oncol 46: 563-568, 2015.

26. Huang YG, Li YF, Wang LP and Zhang Y: Aberrant expression of trefoil factor 3 is associated with colorectal carcinoma metastasis. J Cancer Res Ther 9: 376-380, 2013.

27. Southgate HW: Note on preparing mucicarmine. J Pathol Bacteriol 30: 729, 1927

28. Sobin LH and Wittekind Ch (eds): UICC TNM Classification of Malignant Tumors, 6th edition, John Wiley and Sons, New York, pp52-56, 2002

29. Xiao L, Liu YP, Xiao CX, Ren JL and Guleng B: Serum TFF3 may be a pharamcodynamic marker of responses to chemotherapy in gastrointestinal cancers. BMC Clin Pathol 14: 26, 2014.

30. John R, El-Rouby NM, Tomasetto C, Rio MC and Karam SM: Expression of TFF3 during multistep colon carcinogenesis. Histol Histopathol 22: 743-751, 2007.

31. Gu J, Zheng L, Zhang L, Chen S, Zhu M, Li X and Wang Y: TFF3 and HER2 expression and their correlation with survival in gastric cancer. Tumour Biol 36: 3001-3007, 2015.

32. Pandey V, Wu ZS, Zhang M, Li R, Zhang J, Zhu T and Lobie PE: Trefoil factor 3 promotes metastatic seeding and predicts poor survival outcome of patients with mammary carcinoma. Breast Cancer Res 16: 429, 2014.

33. Garraway IP, Seligson D, Said J, Horvath S and Reiter RE: Trefoil factor 3 is overexpressed in human prostate cancer. Prostate 61: 209-214, 2004.

34. Neutra M and Leblond CP: Synthesis of the carbohydrate of mucus in the golgi complex as shown by electron microscope radioautography of goblet cells from rats injected with glucose-H3. J Cell Biol 30: 119-136, 1996.

35. Suemori S, Lynch-Devaney K and Podolsky DK: Identification and characterization of rat intestinal trefoil factor: Tissue- and cell-specific member of the trefoil protein family. Proc Natl Acad Sci USA 88: 11017-11021, 1991.

36. Taupin D, Ooi K, Yeomans N and Giraud A: Conserved expression of intestinal trefoil factor in the human colonic adenoma-carcinoma sequence. Lab Invest 75: 25-32, 1996.

37. Sands BE and Podolsky DK: The trefoil peptide family. Annu Rev Physiol 58: 253-273, 1996.

38. Mashimo H, Wu DC, Podolsky DK and Fishman MC: Impaired defense of intestinal mucosa in mice lacking intestinal trefoil factor. Science 274: 262-265, 1996.

39. Ullman T, Odze R and Farraye FA: Diagnosis and management of dysplasia in patients with ulcerative colitis and Crohn's disease of the colon. Inflamm Bowel Dis 15: 630-638, 2009.

40. Itzkowitz SH and Present DH; Crohn's and Colitis Foundation of America Colon Cancer in IBD Study Group: Consensus conference: Colorectal cancer screening and surveillance in inflammatory bowel disease. Inflamm Bowel Dis 11: 314-321, 2005.

41. Rutter MD, Saunders BP, Wilkinson KH, Rumbles S, Schofield G, Kamm MA, Williams CB, Price AB, Talbot IC and Forbes A: Thirty-year analysis of a colonoscopic surveillance program for neoplasia in ulcerative colitis. Gastroenterology 130: 1030-1038, 2006. 
42. Kornbluth A and Sachar DB; Practice Parameters Committee of the American College of Gastroenterology: Ulcerative colitis practice guidelines in adults: American college of gastroenterology, practice parameters committee. Am J Gastroenterol 105: 501-523, 2010.

43. Collins PD, Mpofu C, Watson AJ and Rhodes JM: Strategies for detecting colon cancer and/or dysplasia in patients with inflammatory bowel disease. Cochrane Database Syst Rev 19: CD000279, 2006.

44. Hata K, Watanabe T, Kazama S, Suzuki K, Shinozaki M, Yokoyama T, Matsuda K, Muto T and Nagawa H: Earlier surveillance colonoscopy programme improves survival in patients with ulcerative colitis associated colorectal cancer: Results of a 23-year surveillance programme in the Japanese population. Br J Cancer 89: 1232-1236, 2003.

45. Rex DK: Preventing colorectal cancer and cancer mortality with colonoscopy: What we know and what we don't know. Endoscopy 42: 320-323, 2010.

46. Chen R, Rabinovitch PS, Crispin DA, Emond MJ, Koprowicz KM, Bronner MP and Brentnall TA: DNA fingerprinting abnormalities can distinguish ulcerative colitis patients with dysplasia and cancer from those who are dysplasia/cancer-free. Am J Physiol 162: 665-672, 2003.

47. Neumann H, Vieth M, Langner C, Neurath MF and Mudter J: Cancer risk in IBD: How to diagnose and how to manage DALM and ALM. World J Gastroenterol 17: 3184-3191, 2011.

48. Chai $\mathrm{H}$ and Brown RE: Field effect in cancer-an update. Ann Clin Lab Sci 39: 331-337, 2009.
49. Slaughter DP, Southwick HW and Smejkal W: Field cancerization in oral stratified squamous epithelium; clinical implications of multicentric origin. Cancer 6: 963-968, 1953.

50. Watanabe T, Kobunai T, Yamamoto Y, Ikeuchi H, Matsuda K, Ishihara S, Nozawa K, Iinuma H, Kanazawa T, Tanaka T, et al: Predicting ulcerative colitis-associated colorectal cancer using reverse-transcription polymerase chain reaction analysis. Clin Colorectal Cancer 10: 134-141, 2011.

51. Hsieh CJ, Klump B, Holzmann K, Borchard F, Gregor M and Porschen R: Hypermethylation of the p16INK4a promoter in colectomy specimens of patients with long-standing and extensive ulcerative colitis. Cancer Res 58: 3942-3945, 1998.

52. Risques RA, Lai LA, Himmetoglu C, Ebaee A, Li L, Feng Z, Bronner MP, Al-Lahham B, Kowdley KV, Lindor KD, et al: Ulcerative colitis-associated colorectal cancer arises in a field of short telomeres, senescence, and inflammation. Cancer Res 71: 1669-1679, 2011.

(i) $($ ) This work is licensed under a Creative Commons EY NC ND Attribution-NonCommercial-NoDerivatives 4.0 International (CC BY-NC-ND 4.0) License. 